\title{
Book Review: Pachinko by Min Jin Lee
}

Richa Singh

Department of English

Punjabi University

Patiala, Punjab, India

richaagam.926@gmail.com

Pachinko by Min Jin Lee is a saga of the trials and tribulations, joys and sorrows of a Korean family spanning from 1910 to 1989 . Lee is a Korean-American author whose work engages with themes of the diasporic Korean identity. Pachinko was published in 2017 to critical acclaim and it was in the running for the National Book Award for Fiction.

Pachinko is a historical novel and its panoramic gaze encompasses twentieth century Korea giving us a terrifyingly real account of Korean society from the Japanese colonization of Korea to the Second World War. The Financial Times wrote in their review of the book: "We never feel history being spoon-fed to us; it is wholly absorbed into character and story, which is no mean feat for a novel covering almost a century of history."

It is the first novel about Korean history and culture written for English language readers.

Pachinko begins with a quote from Dickens: "Home is a name, a word, it is a strong one; stronger than magician ever spoke, or spirit answered to, in strongest conjuration." It is obvious in Lee's writing that she is deeply influenced by Dickens. Dickens gave us a sweeping gaze of his times and his works too featured many characters - each representing a different stratum of society. 
The book begins with the line: "History has failed us, but no matter." We are introduced to the first generation of the family we will see evolve in the novel. They are financially struggling and hence, politically disenfranchised. They live their life at the margins of Korean society. The novel begins in early twentieth century.

The first people we are introduced to are an ageing fisherman and his wife.They are short on money and decide to take in lodgers in their house while they themselves sleep on the floor of the kitchen. Their son, Hoonie, was born with a cleft palate and a twisted foot but he was of strong build and contributed to the household income by doing manual labour. The people in their village assumed that because he had physical deformities, he must also be mentally lacking but Hoonie was quick-thinking and smart.

In 1910, Japan colonized Korea but to the lives of these ever-toiling peasants, that makes little to no difference. They feel disappointed at their country's corrupt rulers who squandered away Korea but they simply continue their struggle of survival. Each action taken in this house is done so it helps them survive for example, Hoonie's parents send him to school to learn Korean, Japanese and Math so he can keep maintain the ledger in the boardinghouse and so he won't be cheated at the market. The moment Hoonie learns these skills; his parents pull him out of school.

A turning point in their life comes when the village matchmaker visits Hoonie's house. His parents never expected to get a bride for him because Korean society of the time believed that deformities are inherited. The matchmaker said that a widower with four unmarried daughters had asked her to look for a match for them "... since it was better for virgins to marry anyone than to scrounge for food when men and women were hungry, and virtue was expensive." The matchmaker thought that his youngest daughter - fifteen year old Yangjin would be a good match for Hoonie because she was too young to complain about his deformities. 
After losing three children to various diseases, Hoonie and Yangjin are blessed with their daughter - Sunja. As Sunja is growing up, Hoonie's parents pass away and when Sunja is thirteen, Hoonie passes away too. “At his (Hoonie's) burial, Yangjin and her daughter were inconsolable. The next morning, the young widow rose from her pallet and returned to work." Their struggle for survival is passed down to the next generation as they're too poor to mourn.

The story then moves to the 1930s where just like the rest of the world, Korea too feels the effects of The Great Depression.It was common to see "... children going to bed and not waking up, girls selling their innocence for a bowl of wheat noodles, and the elderly stealing away quietly to die so the young could eat."Yangjin and Sunja had managed to make the boarding house a profitable business and were thriving even in the times of the Depression. The guests at their boarding house were fishermen. Yangjin and Sunja would make their meals, wash and mend their clothes for twenty-three yen every month.

These men were the only source of news from the outside world for Yangin and Sunja. They would listen to the news at the docks from other fishermen and discuss it at the boarding house.They would talk about how after conquering Korea, the Japanese were now trying to conquer China.They would say, “Those dwarves can't take over such a great kingdom. China is our elder brother! Japan is just a bad seed." These poor fishermen could only talk ill of their powerful colonizer within the four walls of the boarding house. They thought China could succeed where Korea couldn't -in keeping Japanese colonizers away. Yangjin thought, "Whether China capitulated or avenged itself, the weeds would have to be pulled from the vegetable garden, rope sandals would need to be woven if they were to have shoes, and the thieves who tried often to steal their few chickens had to be kept away." Political developments mean little to the disenfranchised. 
It is at this point of the novel that we are introduced to BaekIsak. He is a protestant minister on his way to Osaka, Japan to live with his brother. Yangjin was shocked when he came knocking at her boarding house. She thinks,"From the looks of him, the man had enough money for a room downtown in a larger inn for merchants or tradespeople...he could've passed for a rich Japanese in the way he dressed."His brother had on his travels stayed at the boarding house and had asked Baek to stay there as well. Baek wanted to try her famous stewed codfish that his brother had recommended. Unfortunately for Baek, his long travel to the island took a toll on him and he fell sick with tuberculosis. Yangjin and Sunja try their best to restore him back to good health.

At this time, Sunja becomes involved with the wealthy fish broker -KohHansu. Koh always kept his eyes on Sunja when she went to the fish market. He would ask her if she was married or not but she never responded. Their relationship changed when a group of Japanese schoolboys tried to attack Sunja and KohHansu saved her. After that incident, Sunja became infatuated with him. Knowing that her mother would forbid her from seeing him, she started to secretly meet him at the stream where she went to wash clothes.

Speaking to him was full of wonder for Sunja. "He lived in Osaka - a large port city in Japan where he said you could get anything you wanted if you had money and where almost every house had electric lights and plug-in heaters to keep you warm in the winter. He said Tokyo was far busier than Seoul -with more people, shops, restaurants, and theatres. He had been to Manchuria and Pyongyang. He described each place to her and told her that one day she would go with him to these places..." Sunja was in awe of him and wanted to be with him. Sunja was waiting for him to ask her mother for her hand in marriage. She dreamt of a comfortable life with him in Osaka.Sunja tried hard to keep up with everything that Koh said andLee gives us a unique Korean simile here: “...yet she crammed her mind the way she 
might have overfilled a pig intestine with blood sausage stuffing. She tried hard to figure things out because she didn't want him to think she was ignorant."

Soon after, Sunja and Koh begin their sexual relationship and Sunja gets pregnant. When Sunja tells Koh about this, he reveals that he has a wife and three daughters in Japan. He said that he had had a string of mistresses but Sunja was the only one to get pregnant and he wonders if she would give birth to a son. He offered to buy her a house in the village and keep her as his mistress. Sunja is devastated when she hears this. Sunja's usual calm and docile demeanor breaks and she says that she would kill herself if he ever tried to see her again. Sunja is consumed with guilt and she wonders how she would tell her mother about the situation. She remembers her father and feels that he would think of her as a whore.

Sunja admits to her mother that she is pregnant but doesn't share who the father is. She says the father of her child cannot marry her as he is already married. Yangjin is very worried for her and she keeps this a secret from everyone except BaekIsak. Even though she herself doesn't believe in God, she feels that she can trust a minister. Baek had almost fully recovered from tuberculosis by this time and he wants to help these women who had cured and taken care of him.Baek was a deeply religious man who was looking for a higher purpose in life. He realizes that by marrying Sunja and giving her unborn child a name, he would be saving her and her mother from ill-repute. This news is welcomed by Yangjin and she is eager for them to marry at the earliest.

They marry and travel to Osaka to live with Baek's brother Yoseb and his wifeKyunghee.Sunja is happy to start a new life in a new city but she is shocked to find that Koreans are treated poorly in Japan and only allowed to take up menial jobs. They soon find out that Yoseb is under heavy debt as he paid for their journey to Osaka. Sunja has to sell the expensive watch that Koh had once gifted her to rescue Yoseb from debt-collectors. 
Sunja goes on to give birth to her son Noa and also has a son with Baek and names him Mozasu. Due to her working-class background, Sunja is desperate to find some work to do in her new home but Yoseb tells her that women from respectable families don't work. However, soon Baek is arrested by the police for charges of encouraging people to worship God and religion instead of the Japanese emperor. He is tortured and beaten in jail. Sunja and Kyunghee begin making and selling kimchi to keep their household income going.

The Second World War ravages Japan and Sunja's family cannot easily get ingredients to make kimchi. Sunja soon gets a job at a restaurant which keeps them a float. Baek is released from prison but he is dying. Sunja is happy to spend her last moments with him.

Sunja finds out that the owner of the restaurant she worked in was none other than Noa's father KohHansu. He has had a change of heart and wants to help Sunja's family and his son with her. After the war ends, Noa and Mozasu start going to college but Noa comes to know of his real father. He feels ashamed and betrayed. Noa and Mozasudrop out of college and work in Pachinko parlours. Pachinko is a game played in Japan akin to casinos in the West. Mozasu eventually marries a Korean girl and has a son named Solomon. Noa moves away from the family and starts living under a fake identity. After many years, Koh tracks down Noa and Sunja begs him to return home. Noa agrees to please his mother but later commits suicide.

Owing to his pachinko business, Mozasu becomes wealthy and sends Solomon to study in New York. After studying, Solomon comes back to Japan and is promptly fired from his job as it is discovered that his father has a pachinko business which is shameful in Japanese society.

Toward the end of the book, we see Sunja visiting Isak's grave and finds out from the groundskeeper that Noa had often visited Isak's grave. She is happy to hear this and keeps 
Noa's photo on Isak's grave. The novel ends with Sunja thinking about her life and all that has happened to her.

Lee takes the readers on a journey spanning the entire twentieth century. Any reader who may not be acquainted with history of Korea and of Koreans in Japan would find this book a fascinating account of bravery and courage.

The title of the book Pachinko is important because it is a common motif in the book. Pachinko is a game that involves gambling. Running a Pachinko parlour is not a respectable business in their society. However, Koreans are treated very badly in Japan and Pachinko parlours are often the only places where they find employment. Mozasu becomes successful in the Pachinko business because he understands that gambling addicts will keep flocking to his parlour if he gives them just enough hope of winning and then taking their winnings away. In a way, Pachinko is a symbol of Koreans in Japan - colonized and disenfranchised. They work hard to change their conditions only to be considered inferior and dirty by the Japanese.Even when Solomon seemingly breaks away from Korean society and studies in USA, on coming back, he is reminded of his past links with Pachinko parlours and fired from his job. Even after getting a good education, the stain of being associated with Pachinko never goes away for him. Being a Korean immigrant is like an inter-generational curse.

Lee has painted a very positive portrait of the Korean family. The family is the locus of love and compassion and the only place where they don't have to ashamed to be themselves. From Hooni's love and care of Sunja to Sunja's love for Noa and Mozasu and Mozasu's love for Solomon - family always cares. Lee also shows us in BaekIsak the power of love and compassion. He was the only true and gentle soul in the novel. Lee shows us that even though traditional Korean society doesn't allow women to live an independent life;strong women like Sunja, Yangjin and Kyunghee protect and save their family in times of need. Yangjin's boarding house business and Sunja'skimchi business keeps their family from 
starvation. Lee shows us the magic that happens when hard-working women get together in solidarity.

As a first-time reader of Korean fiction, I was pleasantly surprised with this book. It is written with such dexterity that the chapters flow from one to the next and the reader quickly gets involved with the characters. We read Korean history and socio-cultural norms via the characters and sympathize with them. Lee tried to humanize all characters and give reasons for their actions - good or bad. Even though the novel is situated in Japan, the issues of identity, migration, stereotypes and discrimination still reverberate today. The emotions of the characters in the book are human emotions that even in 2020, are relevant and can be identified with by readers from many nationalities and backgrounds.

Pachinko is an inspiring story - of how hard work and love can save us in a world of hate. 


\section{Bibliography}

Lee, Min Jin. Pachinko. CPI Group, 2017.

Akbar, Arifa. "Pachinko by Min Jin Lee: Everyday Heroes.” www.ft.com/content/01c1e6ccf75e-11e6-bd4e-68d53499ed71. Accessed on 5 January 2020. 